\title{
Personal hygiene practices with special reference to Towel hygiene practices: An exploratory study
}

\author{
Meenakshi Mishra and Sudha Babel
}

Received: 28.02.2020; Revised: 18.03.2020; Accepted: 03.05.2020

See end of the paper for authors' affiliations

Meenakshi Mishra

Department of Textiles and Apparel Designing, College of

Community and Applied

Sciences, Maharana Pratap

University of Agriculture and

Technology, Udaipur (Rajasthan)

India

Email : meenakshimishra57@

gmail.com
ABSTRACT : Health is the normal and healthy state of body. Health refers to a healthy state of mind and body physically fit to have no disorder, illness or disease. Good personal hygiene is important for both health and social reasons. Personal hygiene is how we care for our body. In bathing, towels play a very important role. Towels are incredibly useful home textiles, whether they used for guest, bath, hand, or beach, all towels share one thing in common: they need to absorb moisture and dry quickly. As they used, they get dirty easily and then smells stingy. The longer towels stay damp, the longer the yeasts, bacteria, molds and viruses remain alive and stay active. Dirty towels can carry a huge variety of microbes, and they've even been linked to spreading infectious disease. The present study was conducted to get the data of towel hygiene. For this purpose hundred respondents were selected. Structured interview schedule was used for data collection. Results revealed that majority of respondents were following unhealthy practices

KEY WORDS: Towel hygiene, Towel washing practices, Drying practices, Recommended hygiene practices

- HOW TO CITE THIS PAPER : Mishra, Meenakshi and Babel, Sudha (2020). Personal hygiene practices with special reference to Towel hygiene practices: An exploratory study. Asian J. Home Sci., 15 (1) : 87-91, DOI: 10.15740/HAS/AJHS/15.1/87-91. Copyright@ 2020: Hind Agri-Horticultural Society. 